\title{
Correlates of contraceptive use among couples in slums of Chandigarh, India
}

\author{
Dinesh Kumar, Navpreet Singh*, Munesh K. Sharma, Naveen K. Goel, Anupama Dhiman
}

Department of Community Medicine, Government Medical College and Hospital, Chandigarh, India

Received: 26 February 2016

Accepted: 23 March 2016

*Correspondence:

Dr. Navpreet Singh,

E-mail: navpreet_4r@yahoo.com

Copyright: (c) the author(s), publisher and licensee Medip Academy. This is an open-access article distributed under the terms of the Creative Commons Attribution Non-Commercial License, which permits unrestricted non-commercial use, distribution, and reproduction in any medium, provided the original work is properly cited.

\begin{abstract}
Background: Population explosion in developing countries is the major problem which neutralizes all the gains and developments achieved in the country. In India, in spite of availability of many contraceptive techniques, the couple protection rate continues to be inadequate. The objective of the study was to compare the fertility behavior of men and women in terms of awareness, preferred and intended use of contraceptives.

Methods: Community-based longitudinal study was conducted among 667 couples in four randomly selected slum areas of Chandigarh using a two-stage systematic sample design. Data was collected using a predesigned and pretested semi-structured interview schedule conducting house-to-house survey. Impact of interventions in the form of health education was assessed at the end of follow-up.

Results: There were 193 (28.9\%) female respondents married before attaining 18 years of age. Medium ages at marriage for women were found to be 18 years. Majority, $91(13.6 \%)$ women delivered first baby prior to 18 years of age. Age wise contraceptive prevalence rate was found to be maximum (66.2\%) among women aged 36-49 years. Contraceptive use was more common in case of nuclear families $(60.4 \%)$ and in case of improvident maternity $(65.3 \%)$. Overall awareness of contraceptives among couples was found to be among $545(81.7 \%)$ couples whereas, only 382 (57.3) were using contraceptives currently.

Conclusions: Migratory couples, having at least one female child, and with history of still births were more likely to use contraceptives. Interventions in the form of health education have some positive role in increasing contraceptive awareness and current as well as intended uses of contraception.
\end{abstract}

Keywords: Contraceptive use, Couples, Improvident maternity, India

\section{INTRODUCTION}

Population explosions in developing countries are the major problem which neutralizes all the gains and developments achieved in the country. Alarmingly rising population has its deleterious effect on developmental efforts. In India, in spite of availability of many contraceptive techniques, the couple protection rate (CPR) continues to be inadequate.

India launched a nationwide family planning programme in 1952, making it the first country in the world to do so. Thus the family welfare programme has travelled a long way, but still fertility control has not reached its desired level. The family welfare programme focused purely on demographic goals and concentrated on numerical, method-specific contraceptive targets till the advent of the "target free approach".

The Reproductive and Child Health $(\mathrm{RCH})$ programme was launched in 1995 under the new RCH approach, state-wide family planning targets were abolished, contraceptive services were offered on demand and gender equity was emphasized. The higher fertility in India is attributed to early marriage, low level of literacy, poor level of living, unmet need of contraceptives and traditional ways of life. ${ }^{2}$ There is a societal preference in India for early marriage soon followed by child-bearing. 
The deep-rooted religious and other beliefs and attitudes and practices favouring large families and militating against contraception have complicated the population problem. High fertility levels resulted in undesired births causing improvident maternity. Improvident maternity is defined as women who had already given birth to three children of whom at least one is alive. It implies occurrence of pregnancy which is not desired for the married couple. The present study was conducted with specific objectives to compare the fertility behaviour of men and women in terms of awareness and preferred use of contraceptives, and future intention to use contraception.

\section{METHODS}

Present study is a part of Indian Council of Medical Research (ICMR) sponsored project conducted in slum areas of Chandigarh. Chandigarh is the most economically advanced Union Territory (UT) of India and capital of two states: Punjab and Haryana, known for its high literacy and good environmental conditions. In spite of high literacy rate for both males $(90.54 \%)$ and females $(81.38 \%)$, Chandigarh shows high fertility level with decadal population growth rate of $17.10 \%$ against $17.64 \%$ for India. ${ }^{3}$ Majority i.e. 1025682 (97.25\%) of its population was urban including slums and 29004 $(2.75 \%)$ was rural population. ${ }^{3}$

Even after banning prenatal sex determination tests, Chandigarh has the lowest sex ratio (818 females per 1000 males) in India. ${ }^{3}$ Sex ratio of urban slum population is even lower than that in the total population in Chandigarh causing so many social problems.

\section{Sampling}

A two-stage systematic random sample design was adopted. At the first stage, from the sampling frame available a sample of four slum areas (colonies), called primary stage units (PSU), was selected with probability proportion to size (PPS). At the second stage, a sample of households as second stage units of was selected systematically within each selected PSU. Within each household, couples having wife in the reproductive age (15-49 years) along with their spouses willing to participate in the study were selected as study units or respondents.

\section{Sample size}

Power analysis was done to calculate optimum sample size. On the basis of pilot survey, percentage of households with improvident maternity as main outcome parameter in the project was found to be $35 \%$ and percentage of couples in the reproductive age was about $25 \%$ of total population. Assuming $90 \%$ confidence coefficient and $10 \%$ (of $35 \%$ ) relative precision, the optimum sample size came out to be 503 households. Design effect due to selection of couples within selected households came out to be 1.26 and hence optimum sample of 634 couples was obtained. Optimum sample size calculated on the basis of contraceptive prevalence rate was even less. Optimum sample size was further elevated in order to adjust drop-outs. Accordingly, ultimate sample included 667 couples only.

\section{Study-design}

Community-based longitudinal study was conducted in four randomly selected urban slum areas of Chandigarh as clusters. Out of four randomly selected clusters, two clusters were randomly assigned to study group and remaining two clusters were assigned to control group. At the baseline/pre-intervention survey, couples in the study group were provided interventions in terms of health education regarding reproductive health/fertility related issues like importance of small family, contraception, legal age at marriage, no gender discrimination, contraceptive awareness and access to contraceptives in a better way, encouragement of spousal communication etc. No active intervention was given to study subjects belonging to control group. At the end of six months of interventions, changes in outcome parameters A few couples who were lost to follow-up due to any reason such as migration, non-availability in spite of repeated visits etc. were excluded from analysis.

\section{Study variables}

Information on socio- demographic characteristics, reproductive behaviour was collected using a predesigned and pretested semi-structured interview schedule conducting house-to-house survey. Respondents were interviewed in privacy at the respondent's home at flexible time points keeping in view of their working hours. All possible efforts were made to reduce nonresponses including frequent visits.

\section{Ethical issues}

Approval by Institutional Research Committee and Institutional Ethics Committee was granted to undertake the project. Informed consent of respondents to take part in the study was taken.

\section{Statistical methods}

SPSS-16 statistical software was used for data analysis. Statistical tests like normal-test, student's t-test, chisquare test, and Analysis of Variance (ANOVA) technique were used for analysing data. Odds ratios along with $95 \%$ confidence intervals were calculated for assessing factors associated with contraceptive use. Multiple logistic regression analysis was used for estimating contraceptive rates on the basis of binary dependent variables. 


\section{RESULTS}

A total of 667 women in reproductive ages and their spouses were interviewed. Table 1 presents comparison of baseline characteristics of current contraceptive users and non-users. There were 419 (62.8\%) couples belonging to nuclear families. Majority of surveyed couples were Hindus $(86.1 \%)$. There were 248 (37.2\%) illiterate women. Majority of women were housewives $(96.1 \%)$. Majority of surveyed couples (89.2\%) were from low socio-economic status (SES). There were 319 (47.8\%) surveyed women belonging to 26-35 years age group and 193(28.9\%) women were married before attaining 18 years of age. Among all surveyed women, 91 (13.6\%) women delivered first baby prior to 18 years of age. There were $227(34.0 \%)$ couples having at least one daughter and $174(26.1 \%)$ couples had at least one son whereas $212(31.8 \%)$ couples had more daughters than sons.

Table 1: Baseline demographic characteristics of couples along with current contraceptive usage.

\begin{tabular}{|c|c|c|c|c|}
\hline Characteristic & $\mathbf{N}$ & Users number (\%) & Non-users number (\%) & P value \\
\hline \multicolumn{5}{|l|}{ Family type } \\
\hline Nuclear & 419 & $253(60.4)$ & $166(39.6)$ & \multirow{2}{*}{$\begin{array}{l}X^{2}=4.45 \\
(\mathbf{p}=\mathbf{0 . 0 3}) *\end{array}$} \\
\hline Joint/Extended & 248 & $129(52.0)$ & $119(48.0)$ & \\
\hline \multicolumn{5}{|c|}{ Socio-economic status } \\
\hline Middle/High & 72 & $40(55.6)$ & $32(44.4)$ & \multirow{2}{*}{$\begin{array}{l}\mathrm{X}^{2}=0.097 \\
(\mathrm{p}=0.75)\end{array}$} \\
\hline Low & 595 & $342(57.5)$ & $253(42.5)$ & \\
\hline \multicolumn{5}{|c|}{ Age of wife (years) } \\
\hline$<18$ & 11 & $01(9.1)$ & $10(90.9)$ & \multirow{5}{*}{$\begin{array}{l}\mathrm{t}=4.47, \\
(\mathbf{p}=\mathbf{0 . 0 0})^{*}\end{array}$} \\
\hline $18-25$ & 204 & $97(47.5)$ & $107(52.5)$ & \\
\hline $26-35$ & 319 & $196(61.4)$ & $123(38.6)$ & \\
\hline $36-49$ & 133 & $88(66.2)$ & $45(33.8)$ & \\
\hline Mean \pm SD & & $30.68 \pm 6.56$ & $28.33 \pm 6.91$ & \\
\hline \multicolumn{5}{|c|}{ Improvident maternity status } \\
\hline No & 376 & $192(51.9)$ & $184(48.9)$ & \multirow{2}{*}{$\begin{array}{l}X^{2}=13.6 \\
(\mathbf{p}=\mathbf{0 . 0 0}) *\end{array}$} \\
\hline Yes & 291 & $190(65.3)$ & $101(34.7)$ & \\
\hline \multicolumn{5}{|c|}{ Having female child } \\
\hline No Female & 440 & $276(62.7)$ & 164(37.3) & \multirow{2}{*}{$\begin{array}{l}X^{2}=15.7 \\
(\mathbf{p}=\mathbf{0 . 0 0}) *\end{array}$} \\
\hline At least one & 227 & $106(46.7)$ & $121(53.3)$ & \\
\hline \multicolumn{5}{|c|}{ Having Male Child } \\
\hline No male & 493 & $306(62.1)$ & 187(37.9) & \multirow{2}{*}{$\begin{array}{l}X^{2}=17.8 \\
(\mathbf{p}=\mathbf{0 . 0 0})^{*}\end{array}$} \\
\hline At least one & 174 & $76(43.7)$ & $98(56.3)$ & \\
\hline \multicolumn{5}{|c|}{ More daughters than sons } \\
\hline No & 455 & $257(56.5)$ & $198(43.5)$ & \multirow{2}{*}{$\begin{array}{l}\mathrm{X}^{2}=0.36 \\
(\mathrm{p}=0.55)\end{array}$} \\
\hline Yes & 212 & $125(59.0)$ & $87(41.0)$ & \\
\hline \multicolumn{5}{|c|}{ Last pregnancy wanted } \\
\hline No & 320 & $192(60.0)$ & $128(40.0)$ & \multirow{3}{*}{$\begin{array}{l}\mathrm{X}^{2}=1.87 \\
(\mathrm{p}=0.17)\end{array}$} \\
\hline Yes & 347 & $190(54.8)$ & $157(45.2)$ & \\
\hline Overall & 667 & $382(57.3)$ & $285(42.7)$ & \\
\hline
\end{tabular}

*Significant

Contraceptive prevalence rate (CPR) was found to be maximum (66.2\%) among women aged 36-49 years (Table 1). Mean age of women using contraceptives $(30.68 \pm 6.56$ years) was found to be significantly higher $(\mathrm{P}<0.001)$ as compared to that for non-users $(28.33 \pm 6.91$ years). Contraceptive use was more common in case of nuclear families $(60.4 \%)$ as compared to their counterparts $(52.0 \%)$ and type of family was significantly associated $\quad(\mathrm{P}=0.03)$ with contraceptive use.
Contraceptive prevalence rate in case of improvident maternity $(65.3 \%)$ was significantly higher $(\mathrm{P}=0.001)$ as compared to that for non-improvident couples (51.9\%). No significant association $(\mathrm{P}=0.75)$ was observed between contraceptive use and SES. Contraceptive use was also found significantly higher $(\mathrm{P}<0.001)$ in case of couples having no male child $(62.1 \%)$ as compared to among those having at least one male child (43.7\%). 
Desire for last pregnancy was not found to be a significant correlate of contraceptive use. $(\mathrm{P}=0.17)$.

Table 2: Fertility behaviour of couples by maternity status.

\begin{tabular}{|c|c|c|c|}
\hline \multirow{2}{*}{$\begin{array}{l}\text { Fertility } \\
\text { Behaviour }\end{array}$} & \multicolumn{2}{|c|}{$\begin{array}{l}\text { Improvident } \\
\text { maternity }\end{array}$} & \multirow{2}{*}{$\begin{array}{l}\text { Total } \\
(\mathrm{N}=667)\end{array}$} \\
\hline & $\begin{array}{l}\text { No } \\
(\mathrm{N}=376)\end{array}$ & $\begin{array}{l}\text { Yes } \\
(N=291)\end{array}$ & \\
\hline \multicolumn{4}{|c|}{ Contraceptive knowledge of wife } \\
\hline No & $75(19.9)$ & $31(10.6)$ & $106(15.9)$ \\
\hline Yes & $301(80.1)$ & $260(89.4)$ & $561(84.1)$ \\
\hline \multicolumn{4}{|c|}{$X^{2}=9.92,(\mathbf{p}=\mathbf{0 . 0 0}) *$} \\
\hline \multicolumn{4}{|c|}{ Contraceptive knowledge of husband } \\
\hline No & $79(21.0)$ & $40(13.7)$ & $119(17.8)$ \\
\hline Yes & $297(79.0)$ & $251(86.3)$ & $548(82.2)$ \\
\hline \multicolumn{4}{|c|}{$X^{2}=5.42,(\mathbf{p}=\mathbf{0 . 0 2})^{*}$} \\
\hline \multicolumn{4}{|c|}{ Contraceptive knowledge of either } \\
\hline No & $73(19.4)$ & $30(10.4)$ & $103(15.4)$ \\
\hline Yes & $303(80.6)$ & 261(89.6) & $564(84.6)$ \\
\hline \multicolumn{4}{|c|}{$X^{2}=9.73,(\mathbf{p}=\mathbf{0 . 0 0})^{*}$} \\
\hline \multicolumn{4}{|c|}{ Contraceptive knowledge of both } \\
\hline No & $81(21.4)$ & $41(14.1)$ & $122(18.3)$ \\
\hline Yes & $295(78.6)$ & $\begin{array}{l}250 \\
(85.1)\end{array}$ & $545(81.7)$ \\
\hline \multicolumn{4}{|c|}{$\mathrm{X}^{2}=6.09,(\mathrm{p}=0.00)^{*}$} \\
\hline \multicolumn{4}{|c|}{ Current contraceptive use } \\
\hline Not using & 184(48.9) & $101(34.7)$ & $285(42.8)$ \\
\hline Using & $192(51.1)$ & $190(65.3)$ & $382(57.3)$ \\
\hline \multicolumn{4}{|c|}{$\mathrm{X}^{2}=13.0,(\mathrm{p}=0.00)^{*}$} \\
\hline \multicolumn{4}{|c|}{ Contraceptive method used } \\
\hline Condom & $\begin{array}{l}141 \\
(37.5)\end{array}$ & $48(16.5)$ & $189(28.3)$ \\
\hline IUD-(Cu-T) & $10(02.7)$ & $11(03.8)$ & $21(03.1)$ \\
\hline Oral Pills & $17(04.5)$ & $15(05.1)$ & $32(04.8)$ \\
\hline Injections & $01(00.3)$ & $01(00.3)$ & $02(00.3)$ \\
\hline $\begin{array}{l}\text { Safe period, } \\
\text { withdrawal }\end{array}$ & $20(05.3)$ & $16(05.5)$ & $36(05.4)$ \\
\hline Female sterilization & $31(08.2)$ & $116(39.9)$ & $147(22.1)$ \\
\hline Male sterilization & $00(00.0)$ & $03(01.0)$ & $03(00.4)$ \\
\hline No response & $66(17.5)$ & $55(18.9)$ & $\begin{array}{l}121 \\
(18.4)\end{array}$ \\
\hline Overall use (CPR) & 192(51.1) & $\begin{array}{l}190 \\
(65.3)\end{array}$ & $\begin{array}{l}382 \\
(57.3)\end{array}$ \\
\hline $\begin{array}{l}\text { Future intention to } \\
\text { use contraceptive } \\
\text { by Wife }\end{array}$ & $215(57.2)$ & $199(68.4)$ & $414(62.1)$ \\
\hline $\begin{array}{l}\text { Future intention to } \\
\text { use contraceptive } \\
\text { by Husband }\end{array}$ & $206(54.8)$ & 194(66.7) & $400(60.0)$ \\
\hline $\begin{array}{l}\text { Future intention to } \\
\text { use contraceptive } \\
\text { by either }\end{array}$ & $\begin{array}{l}218 \\
(58.0)\end{array}$ & $\begin{array}{l}201 \\
(69.1)\end{array}$ & $419(62.8)$ \\
\hline $\begin{array}{l}\text { Future intention to } \\
\text { use contraceptive } \\
\text { by both }\end{array}$ & 203(54.0) & $\begin{array}{l}192 \\
(66.0)\end{array}$ & $395(59.2)$ \\
\hline
\end{tabular}

*Significant
Differentials in awareness and preferred use of contraceptives, future intention to use contraception etc. for improvident and non-improvident groups are provided in Table 2. Contraceptive awareness rates of women as well as of their spouses were significantly higher in case of improvident maternity as compared to their counterparts. Contraceptive awareness of women was found to be significantly associated $(\mathrm{P}<0.001)$ with maternity status. Among 291 improvident couples, 250 (85.1\%) and among 376 non-improvident couples, 295(78.6) both partners were aware of some contraceptive methods. Overall awareness of contraceptives among couples was found to be among $545(81.7 \%)$ couples whereas, only 382(57.3\%) were using contraceptives currently. This gap between knowledge and practice of contraceptive was higher in case of non-improvident couples $(51.1 \%$ Vs $80.6 \%)$ as compared to improvident couples $(65.3 \%$ Vs $85.1 \%)$. Current contraceptive use was found to be significantly associated with maternity status $(\mathrm{P}<0.001)$. Contraceptive prevalence rate (CPR) for improvident group (65.3\%) was significantly higher $(\mathrm{P}<0.05)$ as compared that for non-improvident group $(51.1 \%)$. Condom came out to be the most preferred contraceptive being used by $28.3 \%$ couples including $16.5 \%$ couples in improvident group and $37.5 \%$ in non-improvident group. Permanent methods more specifically female sterilization, were more popular among couples in improvident group. Improvident mothers were more likely (39.9\%) to adopt sterilization as compared to non-improvident mothers $(8.2 \%)$. Respondents were also asked whether they would like to use contraceptives in future irrespective of their current use and found that in baseline survey, intended future use of contraceptives among women and men were found to be $62.1 \%$ and $60.0 \%$. There were $59.2 \%$ couples who intended to use contraceptives in future by the both women as well as by their spouses.

Contraceptive knowledge of women as well as their spouses was found to increase significantly in both the groups (Table 3). Extents of changes in knowledge of couples regarding contraception were comparatively more in study group (from $79.9 \%$ to $95.7 \%$ ) as compared to that in control group (from $89.7 \%$ to $96.6 \%$ ). Also changes in contraceptive prevalence rates were comparatively more in study group (from $57.7 \%$ to $68.1 \%$ ) as compared to that in control group (from $56.7 \%$ to $62.6 \%$ ). There was increase in both awareness and practice of spacing as well as permanent methods for both groups but better outcomes were observed for study group. Use of permanent methods increased among couples who have already attained their desired family size. Proportion of unplanned pregnancies showed more increments for study group as compared to that for control group. Spacing methods were being used even without proper planning and objectives, even by those couples who wanted no more children. For the study group, unmet need of contraception was reduced from existing level of $41.2 \%$ to $29.6 \%$ while it came down from $38.0 \%$ found in baseline survey to only $35.5 \%$ for 
the control group. Intended future uses of contraception by couples were also increase to larger extent in the study group (from $60.1 \%$ to $72.1 \%$ ) as compared to that in control group (from $65.8 \%$ to $72.7 \%$ ).
Table 4 provides multiple logistic regression analysis of factors associated with contraceptive use in the base line survey. Migratory couples, having at least one female child, and with history of still births were more likely to use contraceptives.

Table 3: Comparison of some fertility related outcome parameters in study and control group.

\begin{tabular}{|c|c|c|c|c|}
\hline \multirow[b]{2}{*}{ Outcome parameter } & \multicolumn{2}{|c|}{ Study Group } & \multicolumn{2}{|c|}{ Control Group } \\
\hline & $\begin{array}{l}\text { Survey-I } \\
(\mathrm{N}=348)\end{array}$ & $\begin{array}{l}\text { Survey-II } \\
(\mathrm{N}=348)\end{array}$ & $\begin{array}{l}\text { Survey-I } \\
(\mathrm{N}=319)\end{array}$ & $\begin{array}{l}\text { Survey-II } \\
(\mathrm{N}=319)\end{array}$ \\
\hline \multicolumn{5}{|l|}{ Contraceptive awareness and practice } \\
\hline Contraceptive knowledge of wife & $275(79.0)$ & $333(95.7)$ & $286(89.7)$ & $309(96.9)$ \\
\hline Contraceptive knowledge of husband & $263(75.6)$ & $330(94.8)$ & $285(89.3)$ & $307(96.2)$ \\
\hline Contraceptive knowledge of couples & 278(79.9) & $333(95.7)$ & $286(89.7)$ & $308(96.6)$ \\
\hline Current contraceptive prevalence & $201(57.7)$ & $237(68.1)$ & $181(56.7)$ & $200(62.6)$ \\
\hline Use of permanent method & $70(20.1)$ & $87(25.0)$ & $79(24.8)$ & $92(28.8)$ \\
\hline \multicolumn{5}{|l|}{ Current/past fertility desires } \\
\hline Last child desired by couples & $149(42.8)$ & $176(50.6)$ & $198(62.1)$ & 203(63.6) \\
\hline $\begin{array}{l}\text { Contraceptive use among couples having desire for last } \\
\text { child }\end{array}$ & $84(56.4)$ & $116(65.9)$ & $106(53.5)$ & $124(61.1)$ \\
\hline Last child undesired by couples & $199(57.2)$ & $172(49.4)$ & 121(37.9) & $116(36.4)$ \\
\hline $\begin{array}{l}\text { Contraceptive use among couples having no desire for } \\
\text { last child }\end{array}$ & $117(58.8)$ & $121(70.4)$ & $75(62.0)$ & $76(65.5)$ \\
\hline Unmet need of contraception & $82(41.2)$ & $51(29.6)$ & $46(38.0)$ & $40(35.5)$ \\
\hline $\begin{array}{l}\text { Use of permanent method among couples having no } \\
\text { desire for last child }\end{array}$ & $51(25.6)$ & $58(33.7)$ & $37(30.6)$ & $34(29.3)$ \\
\hline \multicolumn{5}{|l|}{ Wanted birth spacing } \\
\hline Uncertain/unplanned & $184(52.9)$ & 204(58.6) & $220(68.9)$ & $220(68.9)$ \\
\hline Wanted & $73(21.0)$ & $64(18.4)$ & $87(27.3)$ & $78(24.5)$ \\
\hline Not wanted/completed family size & $81(23.3)$ & $80(23.0)$ & $12(03.8)$ & $21(06.6)$ \\
\hline \multicolumn{5}{|l|}{ Use of spacing methods among couples } \\
\hline With uncertain/unplanned birth spacing & $154(83.7)$ & $153(75.0)$ & $166(75.5)$ & $159(72.3)$ \\
\hline Wanted birth spacing & $59(80.8)$ & $51(79.7)$ & $67(77.0)$ & $59(75.6)$ \\
\hline Not wanted birth spacing /completed family size & $65(71.4)$ & $57(71.3)$ & $7(58.3)$ & $9(42.9)$ \\
\hline Overall use of spacing methods & 278(79.9) & $261(75.0)$ & $240(75.2)$ & $227(71.2)$ \\
\hline \multicolumn{5}{|l|}{ Future intentions to use contraceptive } \\
\hline By wife & $205(58.9)$ & $249(71.5)$ & $209(65.5)$ & $232(72.7)$ \\
\hline By husband & $190(54.6)$ & $248(71.2)$ & $210(65.8)$ & $231(72.4)$ \\
\hline By couples & $209(60.1)$ & $251(72.1)$ & $210(65.8)$ & $232(72.7)$ \\
\hline
\end{tabular}

\section{DISCUSSION}

Contraception as a behavioural phenomenon has been the focus of population research. In the present study on contraceptive behaviour, a total of 667 ever married women in the age group 15-49 years and their spouses were interviewed. There were about $29 \%$ female respondents who were married before attaining 18 years of age as compared to $46 \%$ women aged 18-29 years got married before 18 years of age as per reports of the third round of National Family Health Survey (NFHS-3). ${ }^{4}$ Among all surveyed women, $13.6 \%$ women delivered first baby prior to 18 years of age. In NFHS-3, prevalence of teenage pregnancy was reported to be about $16 \%$. In the present survey, about $52.0 \%$ couples reported that last pregnancy was undesired. In the NFHS-3, the percentage of women wanting no more children was found to be $32 \%$. In a study by Sharma et al, it was estimated that half of all pregnancies are unplanned or unintended in Delhi. ${ }^{5}$ Whereas in NFHS-3, $21 \%$ of all pregnancies that resulted in live births in the five years preceding the survey (including current pregnancies) were unplanned. In India, more than three-fourth pregnancies are not planned and one-fourth of them are undesired. ${ }^{6}$ Most couples in India do not want to use a contraceptive method on a long-term basis for the fear of side-effects (especially the oral pill and IUDs), or do not like to use a method linked with coitus (barrier methods). Hence, unwanted and unplanned pregnancies are quite common. ${ }^{7}$ 
Table 4: Logistic regression analysis of risk factors of contraceptive use (Pre -intervention survey).

\begin{tabular}{|c|c|c|c|c|c|c|}
\hline \multirow{2}{*}{ Variable } & \multirow{2}{*}{ B } & \multirow{2}{*}{ S.E. } & \multirow{2}{*}{ Sig. } & \multirow{2}{*}{ OR } & \multicolumn{2}{|c|}{ 95.0\% C.I. } \\
\hline & & & & & Lower & Upper \\
\hline Son preference by couples & -0.635 & 0.494 & 0.198 & 0.530 & 0.201 & 1.394 \\
\hline Undesired last pregnancy & 0.338 & 0.267 & 0.207 & 1.402 & 0.830 & 2.367 \\
\hline Improvident maternity status & 0.131 & 0.303 & 0.667 & 1.139 & 0.629 & 2.065 \\
\hline $\begin{array}{l}\text { Future intention to use contraceptive by either } \\
\text { husband or wife }\end{array}$ & 3.566 & 0.264 & $0.000^{*}$ & 35.370 & 21.093 & 59.312 \\
\hline Educational status of wife & 0.249 & 0.276 & 0.368 & 1.283 & 0.746 & 2.205 \\
\hline Educational status of husband & -0.499 & 0.339 & 0.141 & 0.607 & 0.313 & 1.180 \\
\hline Occupation of wife & -0.339 & 0.625 & 0.588 & 0.713 & 0.209 & 2.425 \\
\hline Type of family & 0.014 & 0.257 & 0.957 & 1.014 & 0.612 & 1.679 \\
\hline Future desire of child by either husband or wife & 0.421 & 0.382 & 0.271 & 1.523 & 0.720 & 3.219 \\
\hline Having male child & -0.515 & 0.361 & 0.154 & 0.597 & 0.294 & 1.213 \\
\hline Having female child & -0.790 & 0.305 & $0.010^{*}$ & 0.454 & 0.249 & 0.826 \\
\hline Having more female children & -0.005 & 0.333 & 0.988 & 0.995 & 0.518 & 1.912 \\
\hline Age of wife & -0.037 & 0.370 & 0.921 & 0.964 & 0.467 & 1.989 \\
\hline Age of husband & 0.455 & 0.511 & 0.373 & 1.577 & 0.579 & 4.295 \\
\hline Marital age of wife & -0.019 & 0.333 & 0.954 & 0.981 & 0.511 & 1.884 \\
\hline Marital age of husband & -0.101 & 0.313 & 0.747 & 0.904 & 0.490 & 1.670 \\
\hline Still births & 1.568 & 0.755 & $0.038^{*}$ & 4.795 & 1.093 & 21.042 \\
\hline Socio-economic Status & 0.187 & 0.377 & 0.620 & 1.206 & 0.576 & 2.525 \\
\hline Migrated & 0.491 & 0.239 & $0.040 *$ & 1.634 & 1.022 & 2.611 \\
\hline Age at first delivery & 0.460 & 0.291 & 0.114 & 1.585 & 0.895 & 2.806 \\
\hline
\end{tabular}

Preference for usage of contraceptive to limit family size is more or less decided by the male partners especially in less developed countries like India. At the baseline survey $84.1 \%$ women and $82.2 \%$ of their spouses reported their awareness of contraception. According to NFHS $-3,{ }^{4}$ knowledge about various temporary and permanent methods among men and women ranges from $45 \%$ to $98 \%$ of women and $99 \%$ of men know one or more methods of contraception. Contraceptive prevalence rates (CPR) were found to be $57.3 \%$. At the baseline survey $83.4 \%$ women and $80.8 \%$ of their spouses reported awareness of female sterilization which increased to $94.8 \%$ women and $93.4 \%$ of their spouses in post-interventional survey. Practice of condoms was also far behind as only $28.3 \%$ couples in the baseline survey were using condoms. In spite of availability of a wide range of contraceptives, mass media campaign and Information Education and Communication (IEC) programme, the population control remains a distant dream to achieve. CPR in India was found to be 56 percent in NFHS-3. Steady increase in the CPR from 41 percent in NFHS-1 to 48 percent in NFHS-2 was observed earlier. ${ }^{8}$ In the study by Kansal et al, CPR was found to be about $49.9 \%$ in Dehradun. ${ }^{9}$ Sharma et al found that $48.2 \%$ of couples use family planning methods in India. ${ }^{10}$ Contraceptive 'ever users' rate in Delhi was found to $75 \%$ in study conducted by Bhasin et al. ${ }^{11}$ The study done in Orissa by Kirkkola et al showed that almost half of the subjects were using some family planning methods. ${ }^{12}$

Men being the dominant decision makers regarding family affairs in developing countries can directly or indirectly affect women's reproductive health. They can promote safe motherhood by planning their families as well as accompanying their partners to meet health provider where they can learn about the available contraceptive methods. Further they can help their partners to use modern contraceptive methods correctly, can encourage them to seek help from health providers if side effects occur and also they can opt for male contraceptive method. Hence, men deserve more attention in the ongoing family planning and other reproductive health programmes for the betterment of their families and community. ${ }^{13}$

The intention to use a method of contraception in the future is an important indicator of the potential demand for family planning services. In present study, $37.9 \%$ women at baseline reported that they do not intend to use contraception in future. For the study group, unmet need of contraception was reduced from existing level of 41.2 to $29.6 \%$ while it came down from $38.0 \%$ to only $35.5 \%$ for the control group. Hence, health education can play an important role in increasing awareness regarding contraception. The community based cross sectional study by Andurkar et al carried out in Aurangabad observed $20.5 \%$ of married women in reproductive age 
had unmet need for contraception, $3.6 \%$ for spacing births and $16.9 \%$ for limiting births. ${ }^{14}$ In present study, the contraceptive knowledge and its use was found to increase significantly, more so for the study group than that for control group. Positive effects of interventions in terms of health talks and demonstrations on family planning methods, dissemination of educational material, free contraceptives and a counselling service etc. are also reported in several other studies. ${ }^{15-18}$ Involvement of husbands in family planning counselling led to joint decisions and encouraged women's use of contraception. ${ }^{19}$

\section{CONCLUSION}

Migratory couples, having at least one female child, and with history of still births were more likely to use contraceptives. Contraceptive behaviour of couples is significantly influenced by improvident maternity status. Interventions in the form of health education have some positive role in increasing contraceptive awareness and current as well as intended uses of contraception. Population specific health education strategies are desired for changing attitudes of women and their spouses and also for other elderly members for promoting contraceptives awareness and practice. Informed consent of respondents to take part in the study was taken.

Funding: Indian Council of Medical Research (ICMR), New Delhi, India (IRIS ID No. 2006-055)

Conflict of interest: None declared

Ethical approval: The study was approved by the Institutional Ethics Committee

\section{REFERENCES}

1. Ministry of Health and family Welfare. Government of India. Annual report. 1996-97.

2. Park K. Test Book of Preventive and Social Medicine. $23^{\text {rd }}$ ed. Jabalpur: Banarasidas Bhanot Publishers 2015: 487.

3. Census of India. Ministry of Home Affairs, Government of India. New Delhi, India. http://www.census2011.co.in/census/state/chandigar h.html. (Accessed 5 Oct 2015).

4. International Institute for Population Sciences (IIPS) and Macro International. 2007. National Family Health Survey (NFHS-3), 2005-06: Mumbai, India.

5. Sharma AK,Grover V, Agrawal OP, et al. Pattern of contraceptive use by residents of a village in South Delhi. Indian J Public Health. 1997;41(3):75-8.

6. Puri S, Bhatia V, Sehgal A, Mangat C. Imparting knowledge of Emergency Contraception to College going students. Is it dangerous? The Internet Journal of Epidemiology. 2008;6:1-10.

7. Encouragement of male participation is a promising strategy for addressing some of the world's most pressing reproductive health problems. Population Reports. New perspectives on Men's participation. 1993;46:3-7.

8. International Institute for Population Sciences (IIPS) and Macro International. 2001. National Family Health Survey (NFHS-2), 1998-99: Mumbai, India.

9. Kansal A, Chandra R, Kandpal SD, Negi KS. Epidemiological Correlates of Contraceptive Prevalence in Rural Population of Dehradun District. Indian J Community Med. 2005;30(2):60-2.

10. Sharma RS, Rajalakshmi M, Sharma RS, Jeyaraj DA. Current status of fertility control methods in India. J Biosci. 2001;26(4 Suppl):391-405.

11. Bhasin SK, Pant M, Metha M, Kumar S. Prevalence of Usage of Difference Contraceptive Methods in East Delhi-A Cross Sectional Study. Indian J Community Med. 2005;30(2):53-5.

12. Kirkkola AL, Mattila K, Virjo I. Problems with condoms - a population based study among Finnish men and women. Eur J Contracept Rreprod Health Care. 2005;10(2):87-92.

13. Wegner M, Landry E, Wilkinson D, Tzanis J. Men as partners in reproductive Health: From issues to action. International Family Planning Perspectives. 1998;24(1):1-13.

14. Andurkar SP, Yadav VB, SD Dalvi. Study of unmet need for family planning among married women of reproductive age in urban health central field practice area of Govt. Medical College, Aurangabad. Indian J Public Health. 2006;50:45-6.

15. Daniel EE, Masilamani R, Rahman M. The effect of community-based reproductive health communication interventions on contraceptive use among young married couples in Bihar, India. International Family Planning Perspectives. 2008;34(4):189-97.

16. Abdulrazaq AG, Kabir S, Mohammad NS, Suleiman IH. The effect of educational intervention on family planning knowledge, attitudes, and practices among married women in a military barrack in northern Nigeria. Afr J Reprod Health. 2014;18(1):93-101.

17. Qian X, Smith H, Huang W, Zhang J, Huang Y, Garner P. Promoting contraceptive use among unmarried female migrants in one factory in Shanghai: a pilot workplace intervention. BMC Health Serv Res. 2007;7:77.

18. Little P, Griffin S, Kelly J, Dickson N, Sadler C. Effect of educational leaflets and questions on knowledge of contraception in women taking the combined contraceptive pill: randomised controlled trial. BMJ. 1998;316(7149):1948-52.

19. Soliman MH. Impact of antenatal counselling on couples' knowledge and practice of contraception in Mansoura, Egypt. East Mediterr Health J. 1999;5(5):1002-13.

Cite this article as: Kumar D, Singh N, Sharma MK, Goel NK, Dhiman A. Correlates of contraceptive use among couples in slums of Chandigarh, India. Int J Reprod Contracept Obstet Gynecol 2016;5:1494-1500. 